\title{
Bio-cultural anchorage of the prickly pear cactus in Tlalnepantla (Morelos), Mexico
}

\author{
Gerardo Torres-Salcido ${ }^{1}$,Alejandro Ramos-Chávez ${ }^{2}$ and Álvaro Urreta-Fernández ${ }^{3}$ \\ ${ }^{1}$ UNAM. Humanities Faculty Latin America and Caribbean Research Center, Circuito Interior s/n, Torre II de Humanidades, piso 3, Ciudad Universitaria, \\ C.P. 04510, Delegación Coyoacán, Ciudad de México. México. \\ e-mail: tsalcido@unam.mx (corresponding author) \\ ${ }^{2}$ UNAM. Information and Library Science Research Institute, Circuito Interior s/n, Torre II de Humanidades, piso 12 , Ciudad Universitaria, \\ C.P. 04510, Del. Coyoacán, Ciudad de México, México. \\ e-mail: aramos@iibi.unam.mx \\ ${ }^{3}$ Consultant to the Rural Production Societies of Tlalnepantla, Morelos, and Alternate Chairman of the Community Property Representatives Committee \\ for the same community. Calle Nacional Número 14, Barrio San Pedro, Tlalnepantla, Morelos, C.P. 62530 \\ e-mail: urreta fernandez@hotmail.com
}

Submitted: 16 July 2015. Accepted: 13 October 2015

\begin{abstract}
The prickly pear cactus is a source of food with strong bio-cultural anchorage in Mexico. This is due to at least three factors: 1) the nature and heritage of cacti; 2) cultural heritage; and 3) the socio-cultural relationships with historical and symbolic roots that have facilitated knowledge of how to cultivate it and how to use it. The aim of this article is to put factors of territorial anchorage and its historical transformation in context by examining the case of the municipality of Tlalnepantla in the state of Morelos, Mexico. This community has experienced accelerated change due to the exchange of traditional crops for the prickly pear cactus and the integration of farming, commercialization and agro-transformation. Our hypothesis is that the market, internal conflicts and a lack of socio-institutional coordination have put social organization into crisis, favoring the territorial spread of the prickly pear cactus and making the Local Agro-Food Systems (LAFS) of Tlalnepantla less competitive. The conclusions highlight important economic and social advances whose roots lie in the strengthening and anchorage of the territory-product. However, circumstances both internal and external to the community persist, such as intra-community conflicts, the international market and cultural paradigm shifts that affect the producers and put consolidation of the LAFS at risk.
\end{abstract}

KEYWORDS: prickly pear cactus; local agro-food system (LAFS); bio-cultural anchorage; Tlalnepantla; collective action; governance.

Citation / Cómo citar este artículo: Torres-Salcido, Gerardo; Ramos-Chávez, Alejandro and Urreta-Fernández, Álvaro (2016) "Bio-cultural anchorage of the prickly pear cactus in Tlalnepantla (Morelos), Mexico". Culture \& History Digital Journal, 5 (1): e008. doi: http://dx.doi.org/10.3989/chdj.2016.008.

RESUMEN: Anclaje bio-cultural del nopal verdura en Tlalnepantla (Morelos), México.- El nopal es un alimento con un fuerte anclaje bio-cultural en México, propiciado por al menos tres factores: 1) la naturaleza y el patrimonio de cactáceas; 2) el patrimonio cultural; $y, 3$ ) las relaciones socio-culturales que han permitido un "saber hacer" y un "saber utilizar" con raíces históricas y simbólicas. El objetivo es situar los factores de anclaje territorial y su transformación histórica tomando como caso el municipio de Tlalnepantla, en el estado de Morelos, México. Esta comunidad ha experimentado un acelerado cambio por la reconversión de los cultivos tradicionales por el nopal y la integración del cultivo, comercialización y agrotransformación. La hipótesis de la que se parte, es que el mercado, los conflictos internos y la falta de coordinación socioinstitucional han puesto en crisis la organización social, favoreciendo la difusión territorial del nopal, haciendo perder competitividad al Sistema Agroalimentario Local (SIAL) de Tlalnepantla. Las conclusiones resaltan importantes avances económicos y sociales que tienen sus bases en el afianzamiento y anclaje del territorio-producto, pero aún existen circunstancias internas y externas a la comunidad tales como conflictos intracomunitarios, el mercado internacional y el cambio de paradigmas culturales que afectan a los productores y que ponen en riesgo la consolidación del SIAL.

PALABRAS CLAVE: nopal verdura; sistema agroalimentario local (SIAL); anclaje bio-cultural; Tlalnepantla; acción colectiva; gobernanza.

Copyright: (C) 2016 CSIC. This is an open-access article distributed under the terms of the Creative Commons Attribution License (CC BY) Spain 3.0. 


\section{INTRODUCTION}

The prickly pear cactus is classified as a species of the genus Opuntia of the botanical family Cactaceae. Different species have been identified that grow principally in arid, semiarid, hot and temperate zones. They can grow from sea level up to about 3000 meters above sea level. Knowledge and use of this plant date to ancient times. Pimienta maintains that it was the first settlers who used it for food more than 25000 years ago, as they moved from north to south through the xeric scrubland of Aridoamérica (Pimienta Barrios, 1990).

In Mexico, the prickly pear cactus has become a plant around which a symbol of national culture has been constructed incorporating myth, history, diet and various other uses that have been essential to life in a large part of the country. It is remarkable that only in Mesoamerica have the leaves of the prickly pear cactus, known as "nopalitos," been used as food by means of a process of dethorning and cutting or by mashing them for juice, which implies age-old knowhow. The fruits of this plant (prickly pears), known in Nahuatl as noch and after the conquest as tuna, have been appreciated as food and valued for their diversity. Finally, a parasitic insect of the prickly pear cactus, the Nopalnocheztli or cochineal, has been the object of the greed of merchants, adventurers and freebooters due to the profits it created in a world eager for the carmine dye for textiles. It is not irrelevant to note that the uses of the prickly pear cactus are not only limited to diet and breeding insects. The prickly pear cactus has had medicinal and cosmetic applications for centuries. It has even been an important construction material due to its properties for producing paint and glue.

Its origin has been associated with environments that are unfavorable to other domesticated plants, as it can grow in arid zones, in soil not suitable for agriculture and in conditions of low moisture. If we had to define the anchorage conditions for this plant, we could say that both food culture and history, the myth of the origins of the Mexican nation, producer organizations, consumers, scientific research and even school education have played an essential role in the conditions for the survival of this cactus in domestic consumption and its growing value for taste, health and international consumption. From a history of having been a marginal plant, often collected in the wild or from backyards, used as a fence to mark property boundaries or as feed for cattle, with production zones located in the center of Mexico and in the arid and semiarid zones of the north, the cultivation and exploitation of the prickly pear cactus experienced dramatic growth in the final decades of the $20^{\text {th }}$ century. Given its urban and industrial transformation, the prickly pear cactus goes beyond its mythology, symbolism, history and use value. Urban consumption turned it into merchandise, and the emigration, as well as an increase in knowledge in the rest of the world of the virtues and properties of this plant, has driven a fever for its production, industrial transformation and consumption.
Under these circumstances, farming areas have arisen that do not correspond to the marginal arid conditions initially required for its care and use. This has led to movements of location and relocation that imply the incorporation of regions and communities to its cultivation, generating collective dynamics of cooperation, conflict and growth of inequality, as well as adaptation of the plant to ecologically diverse environments that influence the transformation of rural landscapes.

In this regard, this article attempts to respond to the question of the anchorage factors of the prickly pear cactus. The Local Agro-Food Systems (LAFS) perspective seems appropriate to broach the question, given the conceptual wealth of its analytical elements. This perspective highlights the anchorage factors of food production. However, it is important to note the limits of this study. The anchorage factors of the specific case, carried out in the community of Tlalnepantla in Morelos state, have problems stemming from the pressure exerted by the close proximity of Mexico City, as well as coordination between organizations and coordination of collective community action.

Nonetheless, this work aims to highlight the roles that myth and history play in local diets as factors little addressed in LAFS studies and, that despite institutional and collective action problems, still play an important role.

In this sense, this article attempts to describe and understand how this plant could be appropriated for production and sale by a community from the north of the state of Morelos, Mexico, whose physical characteristics (wooded semi-humid zone) differ from its production environments. Nonetheless, we also seek to explain how the location of this small community recreates the myths of the prickly pear cactus, its history and usages from the necessities imposed by its close proximity to Mexico City as the largest area of prickly pear cactus consumption. Moreover, we intend to find comprehensive elements on the future of this community, as an example of the thousands of communities existing in Mexico that maintain the establishment of products that have given typicality and a territorial base to foodstuffs, despite the offensive of an enormous food industry and large distribution areas that have imposed changes on the diet and consumption of Mexicans.

The guiding hypothesis for this article is that the cultivation of prickly pear cactus easily and rapidly took root in Tlalnepantla (less than three decades) due to bio-cultural conditions consisting of the soil, social organization, socio-institutional networks with another production territory (Milpa Alta) and the symbolic power that the prickly pear cactus holds for indigenous farmers in Mexico. However, it is also true that this establishment is subject to pressures that have become more acute due to an organizational and institutional crisis and the emergence of other prickly pear cactus production territories.

To further develop these ideas, this article is divided into four sections. The first discusses the concept of biocultural anchorage of foodstuffs. The second highlights 
the role of myth and history in the establishment of agricultural territory, in its power to configure landscapes, institutions and food culture. Section three describes the development of prickly pear cactus production culture in the small community of Tlalnepantla, Morelos, and the dynamic of cooperation and conflict. Finally, we reflect on these local production systems and their future in terms of the governance imposed by urban markets such as that of Mexico City, on the one hand, and from abroad on the other, as well as community conflicts. We conclude with a general reflection on localization and delocalization, addressing the importance of public policies for encouraging healthy eating and territorially based foodstuffs.

\section{BIO-CULTURAL ANCHORAGE}

In the LAFS approach, the conjunction of foodstuffs, culture and territory (Muchnik et al., 2008) plays an important role in analysis of the institutionalism, collective action and quality of a foodstuff, or set of foodstuffs, with a territorial base. In this respect, the LAFS has a powerful historical connotation and dynamic that does not correspond to the idea of closed systems (Pérez Balcázar and Salazar Paredes, 2013). One of the issues that draw the most attention in terms of bio-cultural environments to comprehend the territorial anchorage of foodstuffs is that these are a use value and a public asset that reproduces, is utilized by means of accumulated knowledge of the subject and is exploited by taking into account the territory as a sociocultural construction (Giménez, 1999).

As a public asset, the foodstuff and its anchorage conditions belong to the sphere of what Polanyi (2006) calls the "substantive economy", which is possible to find throughout human history, in opposition to the "autonomous economy" of social relationships that distinguish the modern market, which Polanyi regards as only a few hundred years old. The general characteristic of the substantive economy is that economic exchange, production relationships, consumption and representations of profit are embedded in societies. Therefore, from the point of view of economic sociology, consumption becomes an instrument for moderating inequality and violence in societies (Steiner and Vatin, 2009; Mauss, 2009). It is only the extent to which the market autonomizes itself from the social relationships that public assets such as foodstuffs anchored to territory and knowhow are pressured by demand that can lead to loss of territorial identity due to the effect of delocalization.

However, there is also the emergence of local foodstuffs. Recent literature highlights the growth in demand for foodstuffs with territorial identity. The emphasis on local foodstuffs is attributed to a series of factors, which include the following: a) reduction of the carbon footprint (Coley et al., 2009) by means of consuming nearby foodstuffs; b) the demand to know the origin and traceability of products, as a call to recover what is "natural" and healthy in the context of support groups organized by civil society (Cleveland et al., 2015); and c) nostalgic repre- sentations of consumption championed by migrants or urban consumers (Alonso, 2005).

Chief among the dangers faced by bio-culturally anchored foodstuffs are their labeling as "authentic," "exotic" and healthy products, the plundering of common resources; the consequent loss of conventions, as well as social and community cohesion, due to market pressures; and finally, the appropriation of knowhow on the cultivation, transformation and preparation of the product, which has a decisive impact on the fact that the LAFS may have a phase of decadence due to the effects of relocation. This last is obviously more acute if there are no strong institutions in the territory, if there are no public policies and programs of conservation and reproduction for diverse bio-cultural environments, such as those in Mexico.

In this context comes the question of representing healthy food as a factor that plays both in favor of food value and in its growing relocation. To this end, it is important to recall the plant's properties. The chemical composition of the prickly pear cactus indicates that it is rich in water, cellulose, mucilage, pectin, calcium, vitamin $\mathrm{C}$ and potassium. Besides the above, two types of fiber have been found in the prickly pear cactus that are beneficial to humans.

One is insoluble fiber that stays hard or complete, which contributes to improving the functioning of the digestive system by lubricating its internal walls. The other is soluble fiber formed by the viscous part of the prickly pear cactus, which captures water and contributes to regulating cholesterol and glucose levels in the blood.

To summarize, various attributes of the concept of biocultural anchorage of foodstuffs may be identified schematically: 1) the ecological conditions of the territory and the resources available to plants and animals (Bouche and Moity-Maïzi, 2009); 2) the specific quality associated with said conditions (Muchnik, 2004); 3 ) the knowhow consisting of conveying knowledge and use of specific implements for production (Linck et al., 2006); and 4) production and consumption networks, sometimes called "new" or "alternative" networks that allow negotiations and

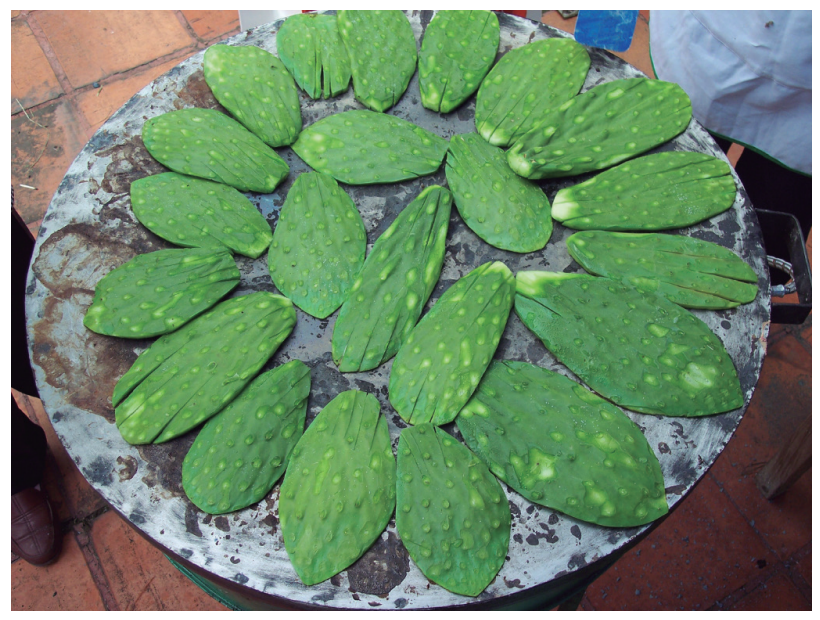

Рното 1. Some prickly pear pads being cooked on a grill pan. Photography by A. Ramos. 
agreements to take place on the quality of the product in question and even the adoption of technological improvements and innovations in agro-industrial transformation and marketing processes (Gill, 2006; Morris and Kirwan, 2011; Raynolds, 2009; Bowen, 2012; Freidberg, 2010).

Nonetheless, as we mentioned in the introduction, the literature on the local and localization has not elaborated on an aspect of bio-cultural anchorage of foodstuffs that could explain the survival of embeddedness from the substantive economy mentioned by Polanyi and of course foodstuffs of a territorial nature, despite the push to diversify production. In this case, we refer to symbolic representations and the role played by myth in consumption. This is something found in the prickly pear cactus, as a typical product resulting from territorial and cultural complexity. We shall now attempt to draw attention to this vacuum in the literature on the LAFS.

\section{MYTH AND HISTORY}

The importance of cacti to the life and culture of the inhabitants of the new continent, especially the prickly pear cactus, was clear to the Spaniards in the $16^{\text {th }}$ century. Fray Bernardino de Sahagún (1981 [1956]) classifies the prickly pear cactus as a "monstrous tree," but does not hide his amazement at the many food uses it offers:

There are certain trees in this land they call nopalli, which means prickly pear cactus. This tree is monstrous: the trunk is composed of the leaves and the branches sprout from the same leaves. These leaves are wide and thick: they have a great deal of juice and they are viscous. There are thorns on the leaves themselves. The fruits of these trees are prickly pears [and] they taste good (...). The leaves of this tree are eaten raw and cooked (Sahagún, 1981: 238).

Francisco Hernández (1959), physician and historian to King Philip II, describes the Nochtli or prickly pear genus:

The varieties of prickly pear are sometimes distinguished by the flowers, which are either saffron-colored with white edges or the same shade of yellow outside and inside as the fruit, as can be seen in the tlatocnocht$l i$, or yellow outside and white with scarlet or yellow as well inside (Hernández, 1959: 311).

This description includes its uses for food, medicine and even as an aid to transport, as he says that "...the Mexicans spread juice from the leaves on the wheels of carts to prevent them from burning from excessive movement" (Hernández, 1959: 935). In fact, he also gives a detailed description of the Nopalnocheztli or Grana de Indias, also known as Cochineal, the parasitic insect that was used as dye and greatly appreciated by French freebooters, who wanted to implement its farming in Haiti and other possessions in the Caribbean (Thiery de Menonville, 2005 [1787]).

The prickly pear cactus is found in the origin of the name of the capital city of the Aztecs, the Tenochtli or

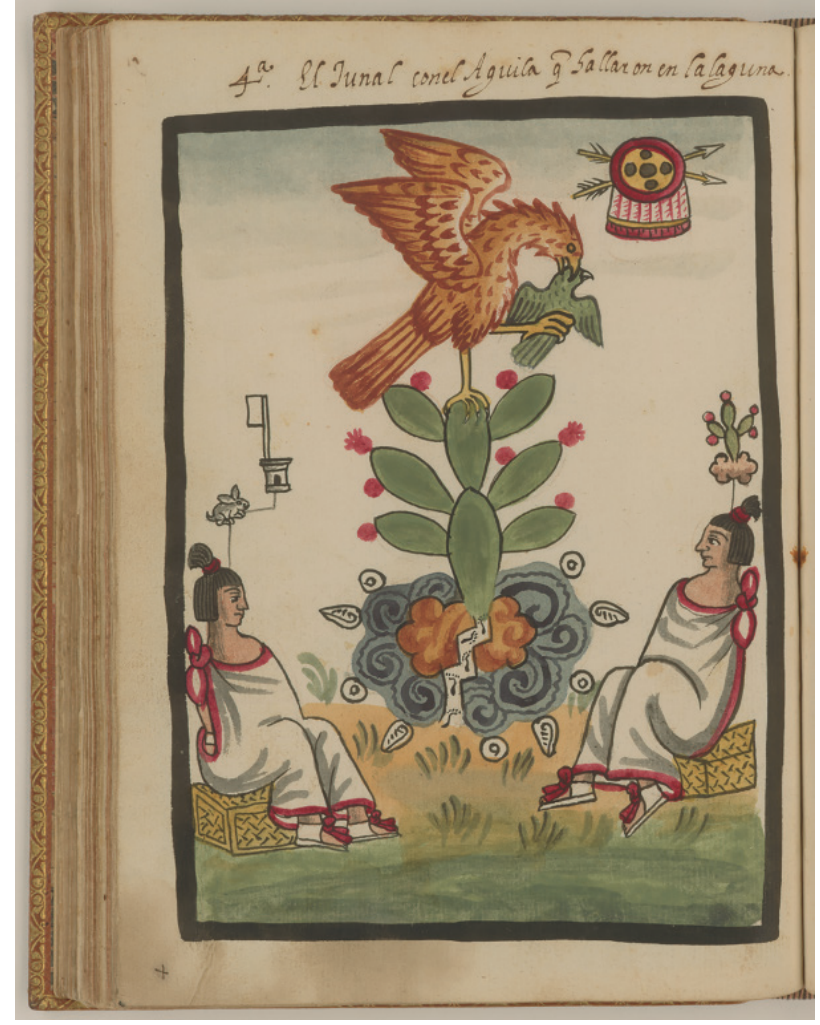

Рното 2. "El Tunal con el Águila que hallaron en la laguna";

De Tovar, Juan (1585): "The Tovar Codex". Photography taken from: http://www.wdl.org/en/item/6749/ [consulted 20/ October/2015].

Stone Prickly Pear is the root of Tenochtitlán, the former name of Mexico City. In his comments on Hernández's work, Isaac Ochoterena, reported "tenochtli" would receive the name of Opuntia ficus-indica (Bravo, 1937 cit. by Hernández and Ochoterena, 1942-1946). Furthermore, the prickly pear cactus refers to the mythological foundation of the city. It was found in the basis of the Aztec prophecy to settle in the land promised by their principal deity, Huitzilopochtli. Angel María Garibay (1964) recovers the myth by translating and interpreting documents from the $16^{\text {th }}$ century: the priest Cuauhtequezqui (who is identified as a representation of Huitzilopochtli) kills Cópil (another god from the Aztec pantheon) and buries his heart in the reeds. He then orders the tribe:

Go and seek a wild prickly pear cactus: there you will see an eagle perched serenely. There it eats, there it preens its feathers and our heart shall be glad at this: There lies the heart of Cópil that you threw there where the water turns and turns! ... That wild prickly pear cactus has sprung up from the heart of Cópil! (Garibay 1964: 36-44).

According to Salvador Novo (1976), it was from this narrative that the prickly pear cactus entered the heraldry and diet of Mexicans. In fact, knowledge of how to use it 
is knowledge of how to eat it, approaching a sacred act. To eat the pulp, the prickly pear must be skinned: the tender leaf must be free of needles and the skin removed. When the tender leaf is pulled off, the prickly pear cactus will yield more leaves, thus providing food generously. Skinning the prickly pear cactus emulates another god from Aztec mythology, Xipe Tótec, the "flayed one," who represented spring and renewal.

Many aspects can be gathered from the bio-cultural or territorial anchorage of the prickly pear cactus, but the mythological and historical dimension of its consumption is one of the most interesting for understanding how this plant is present in the collective imagination of the center and north of Mexico. It is in the composition of its cuisine and in the communities that see common heritage in the cactus and a defense against scarcity and famine. More recently, it is in the formation of all kinds of companies dedicated to farming, transformation and sale of this peculiar vegetable. In this sense, some producers in Tlalnepantla commented the following in interviews:

...Definitely...this product that God offered us and that grows in our town, we are really happy. In good times, and with a little bit of production, you can make some money and keep your family happy and with no need to suffer (Rubio, Fausto; personal communication, 10 June 2008).

In the following section, we shall see through detailed examination that these mythological and historical factors have survived in the farming of this cactus. However, these must be understood within a perspective of cooperation and conflict that is marked by growth in the cities in the center of Mexico and by emigration, as Mexicans have taken their collective imagination, cuisine and culture of fresh indigenous foodstuffs beyond Mexico's borders.

\section{EXPANSION OF THE CULTIVATION AND CARE OF THE PRICKLY PEAR CACTUS. NEW FORMS OF BIO-CULTURAL ANCHORAGE}

If myth plays a role in the collective memory to explain the origin of consumption, historical conditions explain the establishment of the crop in the territories. The historical evolution of the farming and consumption of the prickly pear cactus have gone hand in hand with the economic and urban growth of contemporary Mexico. In 2013, the prickly pear cactus was harvested in more than 12500 hectares of Mexico, with production of $786000 \mathrm{t}$. This gave an average domestic yield of $62 \mathrm{t}$ per hectare and production value of more than 1900 million pesos (more than 142 million dollars at the rate of exchange for December of that year). In addition to this are more than 50000 ha. harvested for prickly pears and 8500 for forage prickly pear cactus (Ministry of Agriculture, Livestock, Rural Development, Fisheries and Food [SAGARPA, acronym as given in Spanish], Agri-food and Fishing Information Service [SIAP, acronym as given in Spanish], 2014). Tlalnepantla is a special case within Mexico, as it has more than $20 \%$ of the surface area for harvesting prickly pear cactus nationwide and it produces approximately $40 \%$ of the product. According to the same source, average yield for this territory is $96 \mathrm{t}$ per ha. It therefore reached a production volume of $231168 \mathrm{t}$ over the year in the 2408 ha. reported as harvested for the 2013 agricultural cycle.

The production value of prickly pear cactus and prickly pear has been an essential driver for new forms of location and relocation of food production. It is primarily of note that the prickly pear cactus is not only gathered or farmed in the marginal and arid lands of the Mexican highlands, with temperate and cold climates in the winter, which reduces production of prickly pear cactus leaves. Its farming has also moved to semi-humid zones that are historically foreign to its production, but which produce it all year round. Farming it puts it into competition with other crops, but above all with the wooded zone.

This is one of the most remarkable changes in the past two decades in which the community of Tlalnepantla, Morelos has been involved.

The prickly pear cactus myth has been recreated by the community - perhaps with a strong marketing emphasis - which classifies its municipality as the "Sacred Land of the Prickly Pear Cactus". Urreta (2007) says that prickly pear cactus farming began in the mid-seventies when a farmer from the Tlalnepantla community brought a prickly pear from Milpa Alta in the south of the Federal District, which he planted close to some fruit trees. In two years, that leaf became several plants, which produced a few sacks of prickly pear cactus that were sold in the Jamaica and La Merced markets of Mexico City. From then on, other farmers from the community began to plant prickly pear cactus, replacing maize and occasionally fruit trees. The act of taking a prickly pear cactus leaf to a different biological and cultural environment, although it was not far away due to the geographical and family closeness, triggered a dynamic of change in Tlalnepantla. To better understand this dynamic, we will examine the

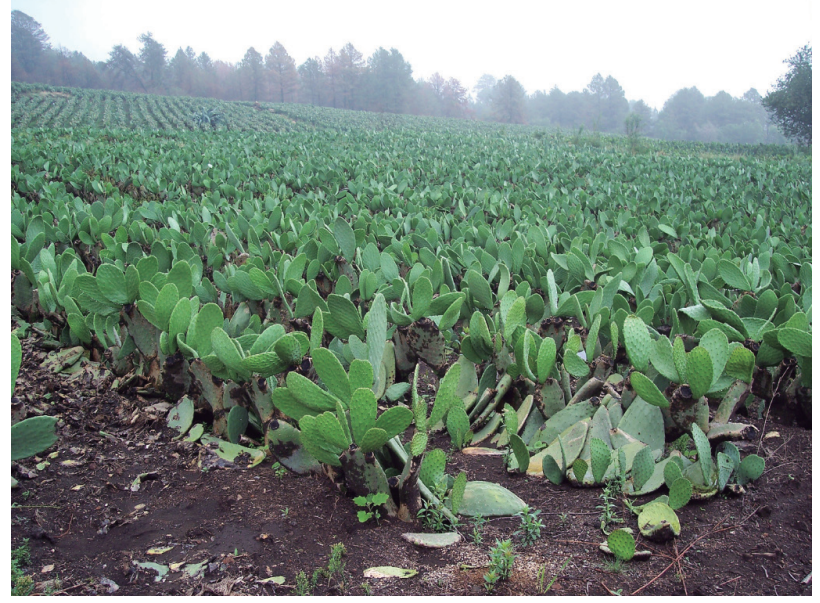

Рното 3. This image shows one of the cases where the prickly pear is cultivated in a humid forest zone. Photography by A. Ramos. 
biological context of the community, its transition towards prickly pear cactus farming and the problems it faces from the largest urban market for consuming prickly pear cactus in the world: Mexico City.

\section{TLALNEPANTLA. ITS BIOLOGICAL CONTEXT}

According to the Encyclopedia of the Municipalities and Districts of Mexico (2010), Tlalnepantla means "in the middle of the land". In reality, it is a village located between the mountains and the lowlands of the state of Morelos, between the coordinates of $18^{\circ} 57^{\prime}$ latitude and $98^{\circ} 14^{\prime}$ longitude west of the Greenwich Meridian (Figure 1). The community of Tlalnepantla is located to the north of the State of Morelos and to the south of Mexico City. It is politically and administratively comprised of Tlalnepantla, which functions as the municipal seat, as well as three adjacent municipalities (El Pedregal, El Vigía and Colinas de San Nicolás) and three subdivisions (Los Robles, El Calmil and Felipe Neri). The municipality is located at an altitude of $2040 \mathrm{~m}$ above sea level and an area of $124092 \mathrm{~km}^{2}$, which represents only $2.5 \%$ of the total area of the state of Morelos. The municipality of

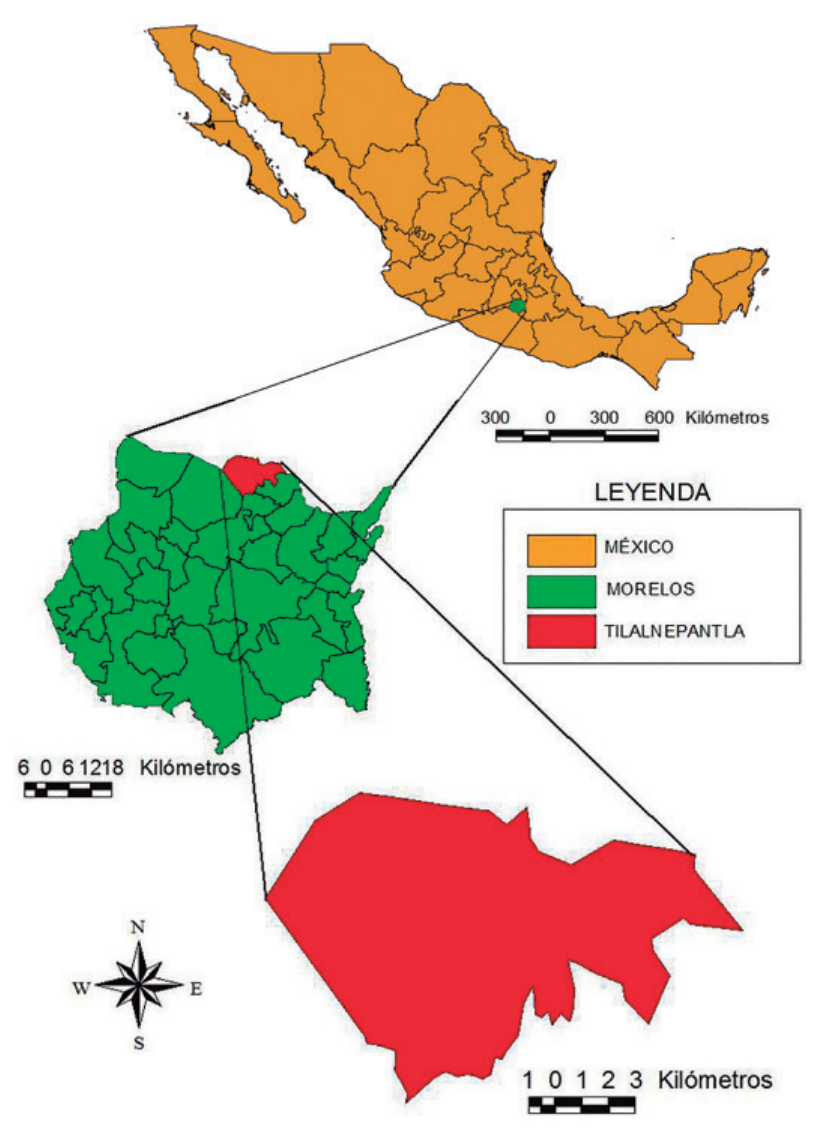

Figure 1. Geographical location of the study area Tlalnepantla, Morelos, México. Source: Rodrigo Meiners, PAPIIT-CONACYT project participant.
Tlalnepantla borders the Morelos communities of Totolapan, Tlayacapan and Tepoztlán, as well as the district of Milpa Alta in the Federal District and the municipality of Juchitepec in Mexico State.

To a large extent, the expansion of prickly pear cactus farming is explained by the climate and soil conditions, as it is temperate sub-humid, with an annual temperature of $17^{\circ} \mathrm{C}$ and average rainfall of $2341 \mathrm{~mm}$, being one of the municipalities of Morelos with the greatest annual rainfall. "The origin of the soil is volcanic, which makes it very acidic. The soil is predominantly 'humus' with the existence of clay. Of the municipality's 12409 ha., 4752.6 are used for agriculture and the rest are forest. There is no irrigation, all watering is seasonal" (Martínez, Norma et al., 2003).

This community has a climate suitable for farming tomatoes, maize, beans, oats and certain fruit varieties, which mainly consist of pears, figs and apples. Another economic activity performed in the municipality, although to a lesser degree, is the breeding of cattle, goats, pigs, sheep and horses. Besides the above, the community is involved in forest exploitation and beekeeping.

The first records on production of prickly pear cactus in the community, according to information provided by oral sources, date from 1981 when farmers from the community began to sell prickly pear cactus at the established markets of Jamaica and La Merced (Fuentes, Teódulo, personal communication, 28 November 2006). However, the statistics given by the District Office of the Ministry of Agriculture, Livestock, Rural Development, Fisheries and Food (SAGARPA, acronym as given in Spanish) in Morelos mention prickly pear cactus production from 1990, with a significant increase from 1998. A change occurred in this period with regard to the economic activities of the community, as the prickly pear cactus monoculture extended in both the number of hectares and production value due to an increase in prices and productivity (Financiera Rural, 2011). The production of other assets that were farmed in the community was reduced considerably with this change, as is the case for beans (which completely disappeared), corn, oats, green tomatoes and wheat.

The phenomenon of prickly pear cactus expansion in certain zones in the center of Mexico that were not historically dedicated to farming this plant is due to various circumstances that range from the large demand created by urban centers, mainly Mexico City, to the strong links between indigenous populations from certain zones in Mexico, as is the case of Morelos, which allowed the exchange of knowledge, culture and assessment of the prickly pear cactus itself. Similarly, there has been an increase in terms of representation of this cactus' value, which to a large degree has allowed the product to become merchandise, above all due to renewed consideration of nutrition and health properties linked to the prickly pear cactus. All these elements constitute very powerful factors in anchorage of the product in specific territories, as is the case for the community of Tlalnepantla. In this regard, in interviews it was mentioned that: 
...it is a product that goes with everything, whatever you put it with, you can put prickly pear cactus with everything; and in addition, it has a lot of properties (Manuel Figueroa, personal communication, 13 June 2008).

On this point, it is relevant to consider the following: What were the reasons that led to change in productive activity of the community? How did the idea of prickly pear cactus production arise? and how did these changes translate into the social and productive organization? We shall attempt to answer these questions below.

In regard to change in economic activity, events related to Mexico's environmental regulations and policy, as well as the involvement of public policy in the structuring and monitoring of ecological conservation zones. In this respect, the municipality of Tlalnepantla and certain other municipalities in the state of Morelos comprise a strip of temperate forest running from east to west that represents an important ecological area in the center of the country. Therefore, the existence of these extensive forests, along with the scenic value they represent, were subject to the implementation of government conservation policies starting in the 1930s, as seen in the decrees creating the "Lagunas de Zempoala" and "El Tepozteco" National Parks in 1936 and 1937, respectively. The municipality of Tlalnepantla was not included in these decrees, so it could continue commercial timber exploitation for the cellulose production company Loreto y Peña Pobre (Urreta Fernández, 2007)

In 1988, these two parks were merged by means of a more extensive conservation area, which now included Tlalnepantla and was called the "Chichinautzin Biological Corridor". It has a total area of 66092.40 ha. of flora and fauna protection, which represents 13.3 of the total territory of the state of Morelos. Ten years later, in 1998, the Ministry of the Environment and Natural Resources (SEMARNAT, acronym as given in Spanish) added the Chichinautzin Biological Corridor to the National System of Protected Natural Areas (SINAP, acronym as given in Spanish), the Ecological Restoration Program and the National Reforestation Program as a result of the forest fires that plagued the country, and specifically the region north of the state of Morelos. This brought with it the allocation of technical, human and financial resources to be used to protect the region's environment ( $\mathrm{Paz}$ Salinas, 2005; Arellano, 2011).

This development of ecosystem protection policies for the area, and chiefly the greater extent and interference of forest protection policies, required the inhabitants of Tlalnepantla, who over many years had become accustomed to obtaining income by means of forest exploitation, to seek new methods for obtaining resources. One of these methods was the exponential development of prickly pear cactus production that affected the community's landscape.

As for why the prickly pear cactus was selected for cultivation in particular, we anticipate that foodstuff anchorage factors, as we have already mentioned, are not only limited to conditions of geographical proximity, but above all to their networks of relationships to other territorial systems and socio-institutional networks. Therefore, in addition to the almost mythological nature of the person who brought a cactus for planting next to a fruit tree, or the fact that there were marriages between the inhabitants of Tlalnepantla and Milpa Alta, there were also government plans that coincided with the interest in farming this cactus in this area. Development of Opuntia Ficus Indica farming was the result of State and Federal governments initiating production development projects that attempted to build on previous organizational community efforts regarding oat production (Ramos Chávez et al., 2008, 2010).

It is plausible that, together with the territory's physical advantages, the social networks that had been established with the territory of Milpa Alta and government interest in encouraging prickly pear cactus production, organization and collective action played a central role in settlement of the product and its identification with the territory. At the beginning of the seventies, farmers from the community started an organizational exercise linked to adult education dynamics supported by the Pablo Freire method. They first organized an oat cooperative to exploit fallow land in the highlands. Then they started productive exploitation of the school plot. Finally, with the prickly pear cactus they began construction of a Rural Production Society (SPR, acronym as given in Spanish), then another and so on until they had five.

SPRs have played an important role that is remarkable to this day and explains the productive rooting. SPRs allowed the community:

1. To have an organizational instrument for directly managing fiscal resources from the government at its three levels.

2. To be an organizational body in the elections to appoint Municipal authorities based on the System of Customs and Practices, ${ }^{1}$ as well as participate by assisting with the call for appointing representatives of communal properties.

3. To assist with the stewardships in organizing and financing town festivals.

In regard to transfers of fiscal resources from the three levels of government, these were exploited by the community for purchasing two-wheel tractors, fumigation equipment and establishing new plantations, among other support.

Both social organization and appropriate use of fiscal resources led to a production dynamic that even led to the construction of organizations such as the NOPALVIDA cooperative, which focused its operation on prickly pear cactus export and processing. They also led to NOCHTLIMEX, a social welfare enterprise incorporated to produce prickly pear cactus on a large scale with added value to benefit more than 200 community associates. Therefore, at the start of the $21^{\text {st }}$ century, Tlalnepantla had great social cohesion and production capacity, and 
controlled both its own market in the Mexico City Central Distribution Center (CEDA, acronym as given in Spanish) and other important urban markets, and exportation (Torres Salcido, 2013).

On the other hand, these changes to the production model have also modified its social, political and economic organization, beyond that of the change to community's landscape, which has been radical. These changes have allowed new scenarios of both cooperation and conflict to appear, related to the restructuring of local power relationships.

In 2008 , there were about 505 prickly pear cactus producers in Tlalnepantla, who harvested a total of 2582 ha. of this cactus, which represented close to $50 \%$ of total community property hectares. Of these producers, 405 were associated in turn with 5 rural production groups that had exclusive access to the sale of the cactus in the local Distribution Center and permits to sell their produce in the CEDA.

Thanks to the collaborative work of all these producers, collective action has developed in the community of Tlalnepantla among the different stakeholders involved in prickly pear cactus production and sale.

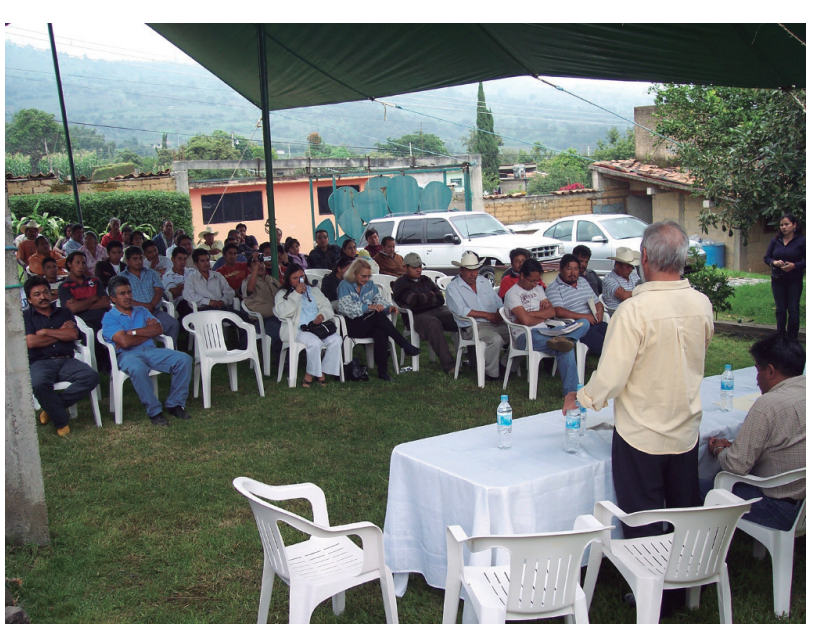

Рното 4. A reunion of the producers organization in Tlanepantla. Photography by A. Ramos.

This collective action has generated both the most important advantages of the case as well as the limitations of the most extensive territorial development of the community as a whole. In regard to sales, it can be said that a large part of the string of achievements and future perspectives on prickly pear cactus production have been possible thanks to the coordination and collective action of a significant number of social stakeholders linked to prickly pear cactus production. We can mention certain specific achievements as an example of this: 1) the formation of rural production groups; 2) obtaining public financing for public and private consultancy, the construction of a Distribution Center in the community, an agro-industrial plant and a tourism development project; 3) entrance and consolidation of produce sales to specialized markets such as the Flower and Vegetable Market of the CEDA (MFH CEDA, acronym as given in Spanish); and 4) sale of goods to other parts of the world, mainly the United States (Ramos Chávez and Torres Salcido, 2014).

This collective action, which can be analyzed among the prickly pear cactus producers within the community, begins to extend itself with cooperation initiatives with other producers from the center of Mexico. The start of joint collaboration with these producers first occurred due to the sale of produce in the CEDA, as they found it useful to be united to defend the sale of their product, as well as to ensure that their demands of the market authorities had greater impact coming from a collective of producers. Due to the above, an informal network of small producers and traders has grown up. Besides the producers from the five production groups of prickly pear cactus from the Community of Tlalnepantla, this includes producers of broccoli, lettuce, chard, spinach, beets, cauliflower, celery, turnips, broad bean, artichokes, green onions and cabbage, among other vegetables, who live and produce in the communities of Xochimilco and Tláhuac in the Federal District and others located in Puebla, Tlaxcala and Mexico State.

However, various coordination problems and conflicts have appeared in tandem with these achievements reached through collective action, as a result of rapid expansion of the LAFS that limit development benefitting the community as a whole.

The first element affecting governance of the system is the community conflict of 2003, which led to modification of relationships of participation not only linked to prickly pear cactus production, but also within the community itself, where there were even families divided by conflicting viewpoints of the conflict (Fernández Christlieb and Urreta Fernández, 2006; Garland Sarah, 2004).

Another problem present in the failure of governance is the manner in which the social capital is formed: the mechanisms of inclusion and exclusion established by the associates. Greater or lesser openness of the organization may correspond to the degree of development and the extent of benefits that could be given to the community. In this regard, when we examine ownership of access to the Distribution Center and the CEDA, we see that each of the five organizations responds to the urban distribution of the municipality, as each of these has a strong territorial base. However, at the same time, their strength does not merely depend on the number of associates, but the surface area harvested, production of the land and other elements that affect their unequal access to the market.

The clearest example of this point can be observed in the unequal access to the CEDA for sale of prickly pear cactus produce. Although all members of the 5 groups are certified for sale in this market, only the first two groups have access to sale in the covered area (inside the CEDA), while the other three are authorized to sell in the sidewalk area, which causes many problems in terms of hours and weather. This point is a bone of contention for the last three groups, as they believe that although everyone is a 
producer from the same town and they are united in various actions and struggles, they are excluded from being able to sell under the same conditions as their colleagues from the first two groups. In the face of this problem, as they are aware that not all groups could fit inside the CEDA, the last three groups have proposed a random system of sales that rotates access to the covered area every month. However, they have obviously met resistance from the groups who already have these advantages.

A further problem could be regarded as falling within the area of governance is coordination with the emerging groups of prickly pear cactus producers from other zones in the state, such as the neighboring municipality of Tlayacapan, which exert increasing pressure on direct sale in the market, but encounter resistance from the Tlalnepantla groups who are already established.

To summarize, even when Tlalnepantla continues to have suitable conditions for bio-cultural anchorage of the prickly pear cactus due to knowledge acquired rapidly over a few decades, due to the quality of its soil favorable to high productivity of the plant, due to the socio-territorial links and networks that extend to the south of the Federal District in Milpa Alta, there are strong pressures to delocalize the system due to the emergence of other productive territories and failures of governance derived from the uncertain coordination exercised from the urban markets that is affecting cohesion of the groups. An example of this was found during interviews which, to an extent could seem discordant, as certain producers argued that:

...as everyone says, and as we say in Tlalnepantla, thanks to the prickly pear cactus we can go out and about, we can go to Cuautla, to water parks, and, as the taxi drivers, the bus drivers, the tortilla shop workers, the shop owners and the small business owners say: when the prickly pear is cheap, sometimes there isn't enough money to buy potatoes, but when it's selling at a good price, everyone in the town does well. So now we all depend on the prickly pear, the producers, the shop owners, the taxi drivers and all the other businesses (Luis Espíndola, personal communication, 17 June 2008)

\section{While other producers think;}

With the prickly pear cactus, sometimes I just want to give up, there are times when the prickly pear cactus doesn't grow; production has expanded a lot and there is a lot of competition. That's why sometimes I feel desperate and I want to give it all up. Yes, that's why I think that the prickly pear cactus isn't the same as it was, it used to be, but now with the other communities cultivating it and that there aren't good markets, well, the price goes down and you find yourself worse off (Luis Romero, personal communication, 20 June 2008).

In this regard, in the next section, we address recent changes in the territory and reflect on the consequences for prickly pear cactus anchorage in contexts that frame strong evolution determined by the market in an attempt to have a comprehensive look at the process.

\section{RECENT CHANGES. TERRITORY AND CONFLICT IN THE ANCHORAGE OF THE PRICKLY PEAR CACTUS}

Bio-cultural anchorage of the prickly pear cactus in Tlalnepantla continues to reflect the characteristics of identity and social organization derived from the indigenous origins of the state of Morelos.

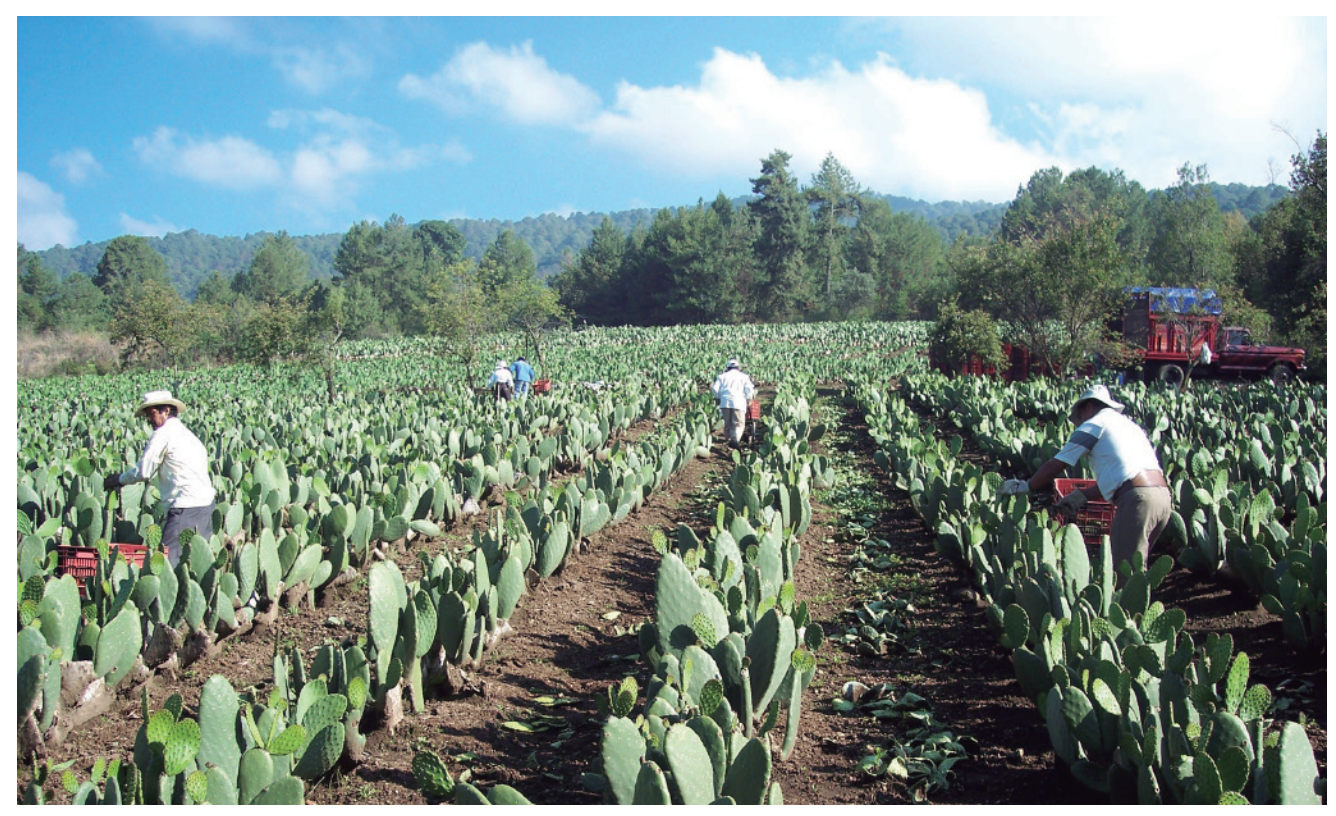

Рното 5. A typical scene during harvest season in Tlalnepantla. Photography by A. Ramos. 
However, as we have seen, the market has generated a dynamic that exposes failures in the governance of this territory, which requires us to reconsider the historical conditions and evolution of the anchorage. Firstly, myth and history, although present, are making way for the need for the spatial spread of prickly pear cactus farming, which means growing delocalization and its perspectives in the face of growing commodification of the product, division in the community and creation of new landscapes. These changes are explained by recent events, which we need to review in order to understand the current effects and future of the crop.

Therefore, although Tlalnepantla seemed sure of its identity and market as a prickly pear cactus producing territory on the rise in 2000 , as there was social coordination willing to facilitate the integration of prickly pear cactus farming groups and planning the integration of the crop with agro-industrial, commercial and tourism projects (Ramos Chávez et al., 2008; Ramos Chávez and Torres Salcido, 2014), there were already market pressures for massification of consumption in the urban population, Mexican emigrants and European or Asian consumers. This led to the price of the prickly pear cactus being fixed not in terms of the season or quality, but supply at an international level. If there was a drop in price in the United States (USA), the same phenomenon occurred within the next two hours in the CEDA (Pérez et al., 2013).

Together with this phenomenon, there was resurgence in local bosses along with an accelerated retreat of the State as a body responsible for encouraging productive activities. Unlike the governments from 1925 to 1994 that had encouraged production activities without excessive clientelism and a more collective vision, although with deformations and insufficiencies, later governments imposed a programmatic focus, individualization of fiscal resources, channeling of the budget towards the agriculture of global agro-businesses and agricultural businessmen who only represented $15 \%$ of all producers, according to the IICA (Robles Berlanga, 2013), thus eliminating government support for social welfare enterprises or organized groups. It is remarkable that this situation has endured for more than 30 years (Ávila Curiel et al., 2011; Cordera Campos, 1981: 24).

Tlalnepantla was not spared from this global neoliberal momentum and is now threatened in terms of the effectiveness of social organizations and their legitimacy with producers. Therefore, the SPRs today find themselves in crisis and transition due to the increase in nonassociated producers, which has threatened territorial anchorage and the formulation of collective projects. It is therefore illustrative that both the NOPALVIDA cooperative is in the process of liquidation and sale of its assets and NOCHTLIMEX is going through a profound paralysis, with the consequent desertion of its partner producers. In this way, the process of organizational construction that had been started several decades before was broken.

In synthesis, we can establish four elements that caused this crisis of collective organization that has af- fected governance of the territory and put anchorage conditions in crisis. These elements are: 1) the costs of transaction in the territory; 2) lack of mechanisms and instruments for improving coordination conditions with academic institutions to effectively encourage agro-industrial innovation; 3 ) the crisis of the power subsystem in the territory and the emergence of new sociopolitical stakeholders, such as political parties; and 4) the crisis in social cohesion derived from criminal violence. We shall review each of these elements:

Intermediation, usually in concert with corruption, has raised the costs of transaction in the territory and complicated governance by increasing the number of intermediary agents who live off public funds and resources designated for supporting producers. As the State has retreated from vital functions for Mexico's productive and social development and encouraged individuals to handle management, exercise and execution of federal resources in the rural environment, a network has been woven of agents whose business is managing government support and reaching agreements with producers, frequently appropriating a part of the resource budgeted and exercised by institutions that legitimately corresponds to the producer.

Due to their own objectives and goals, both public funds and the network of intermediaries seek to establish contracts and agreements with farming organizations that follow government policies or finance individual producer projects. The consequences of this are as follows: 1) raising production costs (due to the imposition of technological packages or supplies associated with the credit, for example) contributing to the neocorporate clientelism that is not, of course, foreign to the government itself; and 2) breaking the intrinsic organization of the SPRs. At present it is more convenient for many producers to manage affairs individually committing bribery and corruption practices instead of covering the obligations of the SPRs based on more specific social conventions, such as fees, fines for delay or breach, specific tasks for looking after market spaces, community tasks, etc.

In regard to the systems of technology transfer to drive agro-industrial innovation, it is necessary to point out that failures in territorial governance have become more acute as they do not have the mechanisms and instruments for coordinating technology transfer, but neither can they generate consensus and agreements in the territory regarding the companies driven by the SPRs. In the case of producer organizations aimed at industrialization and export, NOPALVIDA and NOCHTLIMEX faced the fraudulent action of external businessmen and/or public institutions, provoking a crisis from which they could not escape. For the first, this led to liquidation and for the second, passive stagnation. The fraudulent action against the NOPALVIDA cooperative was both from a supplier in the first phase and from a national farm workers organization in the second phase. This organization unduly appropriated a significant resource belonging to the prickly pear cactus farmer cooperative, which prevented the nec- 
essary infrastructure from being completed to commission the processing plant.

In the case of NOCHTLIMEX, it was abusive actions from private businessmen, in addition to bureaucratic inertia and institutional agreements that led to the installation of machinery of abysmal quality and the absence at the time of operating manuals for the prickly pear cactus processing plant. In this regard, it is of note that in the area and concept of territorial governance, the lack of management abilities in the social groups and their ignorance of the laws, standards and regulations that constitute the legal framework of governance may act in favor of opportunistic agents who at the end of the day work in favor of delocalization of the produce. This delocalization not only undermines practical know-how, but also capacities that the territory had been accumulating, disassembling the knowledge for example, that the companies who are now in crisis or liquidation meant.

As a third element, the crisis in the power subsystem of the SPRs in the territory has led to conflicts that center around a questioning of the customs and practices that have characterized collective decision making. Therefore, the system for electing municipal authorities, which had been established more than four decades ago under the system of customs and practices and allowed social cohesion to be maintained, is breaking down.

The background to this rupture was in the elections of 2003, when a political party, with the support of the State governor, did not respect the election by means of participative democracy, expressed in the community general assembly in an open vote by a raising of hands. The creation of an Autonomous Government received the repressive response of more than 800 police officers and snipers. A NOPALVIDA partner was killed and a large part of the producers' families fled not only their homes, but also their plantations. Some SPR members deserted from this movement never to return again, consequently weakening these organizations.

The reduction of power from the SPRs has become more acute under the political party system. There is widespread disappointment with these, as it is perceived that they have become morally corrupt and ideologically blurred, which deepens conflicts and division in the community, increasing the crisis of territorial identity and that of the former collective decision-making system. Therefore, the role of the already weakened SPRs can hardly maintain the system of participative democracy in the election of municipal authorities. If the violence of the State in 2003-2004 tore apart the fabric of the community, the process today is the coup de grâce. It is possible that the weakening of the community could lead to greater divisions that further weaken the producers' organization.

Finally, criminal violence as a loss of social cohesion in the rural areas of Mexico has been expressed in this territory, which until recently had maintained its distance from the increase in criminal acts that assailed Morelos. The killing of the municipal treasurer in broad daylight and in the facilities of the Municipal Presidency, kidnap- pings of prickly pear cactus producers and the growing extortion and threats experienced by the farmers is slowly putting at risk the peaceful atmosphere for producing and selling.

\section{CONSEQUENCES OF THE CRISIS IN THE PRODUCTION AND SALE OF THE PRICKLY PEAR CACTUS}

The aforementioned failures in territorial governance affect the LAFS cycle that could experience recessive forms in its development or herald the disappearance of territorial anchorage conditions. In this respect, if the biocultural conditions that led to farming prickly pear cactus in Tlalnepantla Morelos, which include myth and history, are maintained, it is clear that there is a spread of the crop that has expanded from Milpa Alta to other zones in the state of Morelos. Therefore we see bio-cultural conditions for territorial settlement that could be recreated in other zones and the process that have been described here show that one factor of territorial settlement such as organization and collective action can experience a historic process of definitive crisis or transformation. This, together with the lack of institutional interest and coordination at the state and federal levels, has contributed to the disinterest in limiting support of the extension to the surface area planted with cacti, the environment and care for the plant. These questions are reflected in the abovementioned consequences of the crisis of territorial governance:

- Weakened SPRs hinder the commissioning of training programs for implementing Good Agricultural Practices and safely combating black spot, prickly pear cactus weevil, mealybug and cochineal, among other pests.

- Working collectively in depth on actions to improve the soil is not occurring either, although fortunately there is traditional knowledge that facilitates the use of organic fertilizer.

- There is no longer organizational clout, as in the past, to pressure government bodies in order to limit support for encouraging prickly pear cactus planting, the expansion of which is putting the economic viability of this crop at risk.

- As rural industries do not operate in the hands of the people, it is not possible to seek out alternative markets from processing of the prickly pear cactus, above all when domestic market prices are falling. This affects producers' income and the spillover that these generate for hundreds of field hands who come to work from indigenous zones of great poverty from La Montaña in Guerrero and the Mixtec Region in Oaxaca, among others.

- Care and defense of the spaces held by the SPRs in the MFH-CEDA is hindered, generating tensions with traders from other regions and the authorities of the CEDA itself.

- The agro-exportation that had been directly experienced, and even placement of produce in state markets, 
has now fallen into the hands of brokers and external traders, connected with local intermediaries. This has led to the loss of profits that used to be in the hands of the Tlalnepantla organizations.

- The capacity for negotiation of the SPRs with different bodies at the three levels of government has diminished. In their place, this has led to management being carried out by national organizations that charge for this both legally and illegally, thus affecting producers' pockets.

Consequently, social cohesion has been undermined, because as happens in many other Mexican territories, social institutional and knowledge networks have. However, there are also elements that allow us to know that the changing conditions of territorial anchorage can be remade with the prickly pear cactus and other products found in the community's productive and organizational memory.

In this context, despite the organizational-productive problems of the SPRs, they continue to operate thanks to their social cohesion. They participate in the maintenance and administration of the Distribution Center in concert with the Municipal Administration. They participate in managing the extension of its infrastructure in order to receive more trucks for shipping prickly pear cactus. They monitor and use the spaces they have in the CEDA, asserting their rights as licensees. They play an important role in the election of the Community Property Representative at times in which forest management has become conflicted as a result of its nature of Protected Natural Area and in turn for boundary conflicts with Milpa Alta (Federal District), Tepoztlán (Morelos) and Juchitepec (Mexico State).

The heart of the matter is that although Tlalnepantla continues producing $40 \%$ of prickly pear cactus nationwide, the market has imposed a structure of networks of intermediaries who separate processes of production from those of industrial transformation and sale. The bulk of the profits are going towards the traders, brokers and transnational agro-industrial processing companies, consequently limiting the accumulation capacity of direct producers.

In view of the crisis of territorial governance that Tlalnepantla is experiencing, production diversification is beginning to occur that at least partially recovers the knowhow accumulated in the pre-prickly pear cactus era. New organizations are now being established that are linked to the production and sale of avocado. A combination of prickly pear cactus plantations with avocado plantations is therefore appearing in the territorial landscape, and there are farming families with both activities in its social makeup, with relatively different proportions according to the decision of the community farmer. However, the risk remains: the territorial supply that the community can achieve now with the combination of prickly pear cactus and avocado may be relocated by the LAFS's weakness to the extent to which the collective organization is weakened. There is little coordination with the three levels of government, scarce integration with aca- demia, which hinders technology transfer and a large urban market in the center of the country that puts pressure on traditional arrangements in the territory.

Strictly speaking, it is necessary to rescue the symbolic value of the products, social organization and territorial organizational processes to establish new anchorages of economic and social viability for Tlalnepantla, such as social organization transformed into a regulating council and establishing forms of intercommunity transfer of knowledge on the cultivation, care and transformation of the plant.

\section{CONCLUSIONS}

Among the factors of territorial anchorage of foodstuffs, bio-cultural contexts include geographical and institutional proximity that are formed from networks of social and institutional relationships. Among the latter, symbolic representations of a product may be considered, as well as the historical conditions found in the basis of institutions. If we consider these last as frameworks that determine the behavior of men and women in society, history and symbolic representations are a powerful factor for anchorage of food cultures.

However, if food cultures arise from this bio-cultural anchorage, the conversion of products into goods that tend to abandon their location to start an uncontrolled commercial venture, this means the undercutting of substantive economies based on the bio-cultural use of plants and foodstuffs. These conditions suggest the question on the expiry or perpetuity of anchorage factors, despite the fact that symbolic representations endure in the collective memory. In the case of Tlalnepantla, it has been shown that a paradox arises from growing delocation of the product that despite the prickly pear cactus being bio-culturally and historically established, spatial distribution of the networks that led to its origin in the Milpa Alta LAFS are now in crisis as a consequence of the conflicts and failures in governance and due to the evolution in social organization and collective action that is ceding to the autonomous market. The case of Tlalnepantla shows that factors of anchorage and de-anchoring may evolve rapidly in a matter of decades.

In this sense, the LAFS perspective was useful to understand territorial anchorage and de-anchoring in Tlalnepantla; however, it is important to mention that, due to the specific nature of articulation and disarticulation/convergence and de-convergence/cooperation and conflict, the results of the studies using a LAFS perspective are different when comparing European cases to those in Mexico; the sociocultural differences result in a wide complexity to understand the realities of Mexico, that in turn results in a difficult exact applicability of the elements contained in European LAFS. Considering all of this, we can say that the anchorage of the product is still present in the analyzed territory, although it is important to note that it is under multiple pressures, such as the demands of massive sale and consumption markets, which put the continuity of the system at risk. 
Similarly, it is important to note that in the context of Latin American countries, we can observe that the emergence of the monetary economy and the weakening of collective action can trigger forms of exclusion, inequality and power that were already present in local system of bosses (caciquismo), but now work together with greater risks, such as crime or violence.

Does the above mean that it is not possible to develop equitable economies from LAFS that recognize their strength in anchorage processes? The answer is no, as can be seen in the final part of this chapter. Localization can find new expressions. Thus, just as the prickly pear cactus LAFS of Milpa Alta facilitated the spread of prickly pear cactus production in the territory, creating another LAFS in Tlalnepantla, it is clear that if the production process can be relocated, new forms of anchorage can occur based on knowledge, on territorial intelligence. On the other hand, cultural biodiversity of the territories can lead to other forms of localization (avocado, for example) of handicrafts, industrial transformation and tourism, for example. We insist that to do so it is necessary to emphasize collective action and coordination of agents in the territory.

\section{ACKNOWLEDGMENTS}

To the anonymous reviewers and Javier Sanz Cañada, for their valuable comments, to Isaac Meneses Lara, for bibliographic support, and to Zoe Phillips and David Morales Córdova, for their assistance in editing the document's translation. To the Humanities Coordination of the UNAM, for granting use of its facilities. To the Directorate General of Academic Personnel Affairs (DGAPA, acronym as given in Spanish) of the UNAM and the National Science and Technology Council (CONACYT, acronym as given in Spanish), for financing the PAPIIT IT 300113 and CB 181616 projects, respectively, within the framework of which this research was carried out.

\section{NOTES}

1 By the Customs and Practices system, we understand the practices and traditional ways to carry out political and social processes in certain communities in Mexico. These practices are based -and openly accepted by the community- in informal institutions; that is, even though they do not have an established legal regulation.

\section{REFERENCES}

Alonso, Luis E. (2005) La era del consumo. Siglo XXI, Madrid.

Arellano López, Jessica G. (2011) Corredores biológicos y reconfiguración territorial en América Latina: los casos de Chichinautzin, México y San Juan-La Selva, Costa Rica. (Senior Thesis), Colegio de Estudios Latinoamericanos, Universidad Nacional Autónoma de México, México D.F.

Ávila Curiel, Abelardo; Flores Sánchez, Jesús and Rangel Faz, Gabriela (2011) La política alimentaria en México. Centro de Estudios para el Desarrollo Sustentable y la Soberanía Alimentaria, Cámara de Diputados, LXI Legislatura, México.

Bouche, Rémi and Moity-Maïzi, Pascale (2009) "Ecology and culture: The territorial anchorage of Corsican cheese producers' knowledge". Outlook on Agriculture, 38 (6): 183-188. doi: http://dx.doi.org/10.5367/000000009788632421.

Bowen, Sarah (2012) "Las indicaciones geográficas, la globalización y el desarrollo territorial: El caso del tequila". Agroalimentaria, 18: 91-103.

Bravo Hollis, H. (1937) Las cactáceas de México. UNAM, Imprenta Universitaria, México

Cleveland, David A.; Carruth, Allison and Niki Mazaroli, Daniella (2015) "Operationalizing local food: Goals, actions, and indicators for alternative food systems". Agriculture and Human Values, 32 (2): 281-297. doi: http://dx.doi.org/10.1007/s10460014-9556-9.

Coley, David; Howard, Mark and Winter, Michael (2009) "Local food, food miles and carbon emissions: A comparison of farm shop and mass distribution approaches". Food Policy, 34 (2): 150-155. doi: http://dx.doi.org/10.1016/j.foodpol.2008.11.001.

Cordera Campos, Rolando (1981) México: La disputa por la nación, perspectiva y opiniones del desarrollo. Siglo XXI, México.

Fernández Christlieb, Paulina and Urreta Fernández, Álvaro (2006) "Tlalnepantla, Morelos: Un esfuerzo colectivo por la autonomía". In Movimiento indígena en América Latina: Resistencia y proyecto alternativo, edited by Gutiérrez, Raquel and Escárcega, Fabiola. UAM-X, México: 122-133.

Financiera Rural, México [FR]. (2011) "Monografía del Nopal y la Tuna", July. http://siproduce.sifupro.org.mx/seguimiento/archivero/14/2013/anuales/anu_2251-6-2014-05-26.pdf [consulted 09/February/2016]

Freidberg, Susanne (2010) "Perspective and power in the ethical foodscape". Environment and Planning, 42: 1868-1874. doi: 10.1068/a43217.

Garibay, K. and Ángel, M. (1964) La literatura de los aztecas. Joaquín Mortiz, México.

Garland, Sarah (2004) "Mexico: Tlalnepantla uprising". NACLA Report on the Americas, 37 (5): 45-46.

Gill, Seyfang (2006) "Ecological citizenship and sustainable consumption: Examining local organic food networks". Journal of Rural Studies, 22: 383-395. doi: 10.1016/j.jrurstud.2006.01.003

Giménez, Gilberto (1999) "Territorio, cultura e identidades. La región sociocultural". Estudios sobre las culturas contemporáneas, 5: 25-57.

Hernández, Francisco (1959) Historia natural de Nueva España. Universidad Nacional de México, México.

Hernández, Francisco, and Ochoterena, Isaac (1942-1946) Historia de las plantas de Nueva España. Imprenta Universitaria, México.

Linck, Thierry; Barragán López, Esteban and Casabianca, François (2006) "De la propiedad intelectual a la calificación de los territorios: Lo que cuentan los quesos tradicionales". Agroalimentaria, 22: 99-109.

Martínez, Norma Leticia; Tenorio, Hugo and Urreta Fernández, Álvaro (2003) Identificación de proyectos para el grupo nopalvida SCL. Unpublished manuscript, México.

Mauss, Marcel (2009) Ensayo sobre el don: forma y función del intercambio en las sociedades arcaicas, translated by Julia Bucci. Ed. Katz, Buenos Aires.

Morris, Carol and Kirwan, James (2011) "Ecological embeddedness: An interrogation and refinement of the concept within the context of alternative food networks in the UK". Journal of Rural Studies, 27: 322-330. doi: 10.1016/j.jrurstud.2011.03.004.

Muchnik, José (2004) "Calidad e identidad territorial de alimentos. Alimentar el cuerpo humano y el cuerpo social". In Memorias del Congreso Internacional Agroindustria y Territorio - ARTE, december 1-4, edited by Álvarez Macías, Adolfo; Boucher, François; Cervantes, Fernando and Espinoza Ortega, Angélica. Universidad Autónoma del Estado de México, (UAEMEX) Toluca, México: 13-24.

Muchnik, José; Sanz Cañada, Javier and Torres Salcido, Gerardo (2008) "Systèmes agroalimentaires localisés: État des recherches et perspectives". Cahiers Agricultures, 17: 513-519. doi: 10.1684/agr.2008.0251.

Novo, Salvador (1976) Cocina Mexicana o Historia Gastronómica de la Ciudad de México (4th. ed.). Porrúa, México. 
Paz Salinas, María F. (2005) La participación en el manejo de áreas naturales protegidas. actores e intereses en conflicto en el Corredor Biológico Chichinautzin, Morelos. UNAM - CRIM, México.

Pérez Balcázar, Anthony and Salazar Paredes, Lizeth J. (2013) "Desarrollo endógeno y clausura operativa territorial. Una aproximación al estudio del desarrollo desde la perspectiva sistémica (el caso Tlalnepantla, Morelos, México)". Revista de Economía del Caribe, 11: 144-180.

Pimienta Barrios, Eulogio (1990) El nopal tunero. Universidad de Guadalajara, Guadalajara, México.

Polanyi, Karl (2006) [1957] La gran transformación: Los orígenes politicos y económicos de nuestro tiempo (2nd ed.). Preface by Stglitz, Joseph. Introduction by Block, Fred, Translated by Suárez, Eduardo and Rubio, Ricardo. Fondo de Cultura Económica, México.

Ramos Chávez, Alejandro and Torres Salcido, Gerardo (2014) Gobernanza de los Sistemas Agroalimentarios Localizados: el caso de los productores de nopal en Tlalnepantla, Morelos. UNAMCoordinación de Humanidades, México.

Ramos Chávez, Alejandro; Torres Salcido, Gerardo and Urreta Fernández, Álvaro (2008) "Construcción y configuración de un Sistema Agroalimentario Local". In IV Congreso Internacional de la Red SIAL. Sistemas Agroalimentarios Localizados. Alimentación, Agricultura familiar y Territorio (Alfater 2008), edited by Elverdín, Julio. INTA, Mar del Plata, Argentina.

Ramos Chávez, Alejandro; Torres Salcido, Gerardo and Urreta Fernández, Álvaro (2010) "Nopal y comunidad en Tlalnepantla, Morelos". La jornada del campo. February 13 ${ }^{\text {th }}$. (Suppl.) III (29): 11.

Raynolds, Laura T. (2009) "Fair trade". In International encyclopedia of human geography, edited by Kitchin, Rob and Thrift, Nigel. Elsevier, United Kingdom: 8-13.
Robles Berlanga, Héctor. (2013) "Las pequeñas unidades de producción: Una alternativa para superar la pobreza y producir alimentos". In El derecho a la alimentación en México. Recomendaciones de la sociedad civil para una política pública efectiva, edited by OXFAM. OXFAM-CRECE, México: 91-99

Sahagún, Bernardino de (1981) Historia general de las cosas de Nueva España, (4th ed.). Porrúa, México.

Secretaría de Agricultura, Ganadería, Desarrollo Rural, Pesca y Alimentación (SAGARPA) \& Servicio de Información Agroalimentaria y Pesquera (SIAP) (2014) Servicio de información agroalimentaria y pesquera. Retrieved from http://www.siap. gob.mx/cierre-de-la-produccion-agricola-por-cultivo/ [consulted 17/May/2015]

Secretaría de Gobernación (SEGOB) \& Instituto para el Federalismo y el Desarrollo Municipal (INAFED) (2010) Enciclopedia de los Municipios y Delegaciones de México. Estado de Morelos.

Steiner, Phillipe and Vatin, François (eds.) (2009) Traité de Sociologie Économique. Presses Universitares de France (PUF), Paris, France.

Thiery de Menonville, Joseph (2005) [1787] Tratado del cultivo del nopal y de la crianza de la cochinilla, precedido de un viaje a Guaxaca. Consejo Nacional para la Cultura y las Artes (CONACULTA), México.

Torres Salcido, Gerardo (2013) "Los retos de la política pública frente a los problemas de la seguridad y la soberanía alimentarias". In El derecho a la alimentación en México: Recomendaciones de la sociedad civil para una politica pública efectiva, edited by OXFAM. OXFAM, CRECE, México: 51-57.

Urreta Fernández, Álvaro. (2007) Una experiencia colectiva de resistencia y autonomía: Tlalnepantla, Morelos, 1976-2006. Universidad Autónoma Metropolitana-Xochimilco, México. 